\title{
The comparison of pollen abundance in air and honey samples
}

\author{
Ingrida Šauliené $\dot{*}^{*}$, Laura Šukienè, Auste Noreikaite-Merkeliene, Vidmantas Pileckas \\ Department of Environmental Research and Physics, Faculty of Technology and Natural Science, Siauliai University, Vilniaus 141 - 415, Šiauliai 76353, Lithuania
}

\begin{abstract}
Honey as a food has long been used in human nutrition and is still popular. Honey is important because of its therapeutic, prophylactic and strengthening value. Pollen is one of the most decisive components that ensure the quality and type of honey. Modern society becomes more and more sensitive to airborne pollen. Therefore, it is crucial to determine the composition of allergenic plant pollen in natural honey. For this purpose, we studied and compared pollen abundance in honey and air samples collected in Lithuania. Standard methods for pollen investigation in air and honey were used in this study. The botanical diversity of pollen identified in honey and air samples indicates 10 morphotypes: 8 of woody plants and 2 of herbaceous plants, in both the honey and air samples. Salix pollen counts in the honey were found to be highest among airborne pollen from May to September. The anemophilous allergenic pollen constituted $44 \%$ of the total pollen detected in the honey.
\end{abstract}

Keywords: allergy; airborne pollen; Apis mellifera; food safety; Lithuania

\section{Introduction}

The honey market globally covers more than 150 countries [1]. Honey production and consumption are an integral part of the culture and economy of many countries, including Lithuania. Bee products are marketed as healthy and quality food having therapeutic, prophylactic and strengthening properties.

Honeybee (Apis mellifera L.) usually collect pollen from entomophilous plants that secret nectar. Along with pollen from enthomophilous species, anemophilous pollen with allergenic properties often gets into bee products [2-4]. Accidental inclusion of airborne pollen in bee products can be due to several reasons: bee nutrition habits, weather conditions, plant diversity across an area, and others. Honeybee diet consists of nectar, pollen and water [5] occurring in the surrounding of the hive, usually within a radius of $3 \mathrm{~km}$ around the hive [6]. In case of unfavorable foraging conditions, bees can fly a distance from 5 to 10 kilometers in search of food and water [7]. Bees collect pollen mainly during warm, calm weather, even when it is cloudy, but once the rain starts the collection of pollen discontinues and bees return into hives [6]. Pollen can be found in all bee products. Pollen gets into honey in different ways (mostly when bees collect nectar), and its amount depends on the type of honey and the gathering period. For example, the amount of pollen in royal jelly ranges from $20 \%$ to $45 \%[7,8]$.
Bee products are important for human nutrition. A daily dose of 20 grams of honey will cover about $3 \%$ of the required daily energy [9]. Honey is primarily composed of carbohydrates which constitute about $95 \%$ of its dry weight [10]. Pollen is the main source of honey amino acids and the amino acid profile of a honey could be characteristic of the pollen botanical origin. Climat change and the increasing number of people with alleries to pollen [11], might need to consider bee products not only as a full-fledged source of proteins, lipids, vitamins, minerals and biologically active substances but also a potential source of allergens causing adverse allergic reactions that undermine the quality of life. Today, allergy is a pandemic public health problem; more than 150 million people suffer from allergy symptoms in Europe [12]. It is estimated that by 2025 more than $50 \%$ of all Europeans will suffer from allergy, and every third child will exhibit increased sensitization and stronger reactions to allergic rhinitis. However, the ingestion of honey at high doses, in addition to the usual standard medication, affected the recovery of the symptoms of allergic rhinitis [13]. Most of allergenic pollen in the air is spread by anemophilous trees. The concentration of allergenic pollen can reach thousands of pollen grains in a cubic meter of air [14].

The aim of the study is to determine what types of anemophilous plant pollen can be found in honey and to compare pollen abundance in honey and air samples.

* Corresponding author. Email: ingrida.sauliene@su.lt

Handling Editor: Bożena Denisow 


\section{Material and methods}

\section{Sample collection}

Honey samples were collected every 10 days in an apiary in Radviliškis district (northern Lithuania) from May to September 2013. The area of the apiary where the bees collect nectar, honeydew, and pollen is surrounded by forests of Tilia L., Betula L., Picea Mill., Pinus L., and orchards of Malus Mill., Cerasus Mill., Prunus L., Ribes L. The bees flying area (within a radius of $3 \mathrm{~km}$ ) is dominated by cultivated agricultural fields. During the sampling period, winter and spring rapes and various cereals (wheat, rye) were cultivated in crop fields.

Air samples were collected in Šiauliai from March to September in 2013. Air pollen was captured in a Hirst type volumetric trap installed in the central part of the city, 152 $\mathrm{m}$ above sea level ( $18 \mathrm{~m}$ above the ground). The flora in the close areas consisted of street tree planting and greenery belts. The trees Tilia L., Betula L. Aesculus L., Acer L. were predominant in greeneries.

The distance between the volumetric trap and the apiary was $\sim 30 \mathrm{~km}$. This distance allows [15] the pollen content in the air near the apiary to be reflected properly.

\section{Sample identification}

The samples were specially treated to determine the floral composition of honey and the concentrations of pollen [16]. $10 \mathrm{~g}$ of honey were dissolved in $20 \mathrm{ml}$ of distilled water and centrifuged for $10 \mathrm{~min}$ at $3000 \mathrm{rev} / \mathrm{min}$. The top layer of the solution was then removed, $10 \mathrm{ml}$ of water added and centrifuged for $5 \mathrm{~min}$. The top layer of the solution was removed, leaving from $0.1 \mathrm{ml}$ to $0.3 \mathrm{ml}$ of the solution on the deposition. For microscopy, $0.1 \mathrm{ml}$ of the stirred deposition was dripped on a slide and dried. Pollen identification was performed three times with a magnification of $400 \times$ [2]. For analysis, the number of pollen grains in honey was counted using standard methods [16].

Airborne pollen data from air samples collected in sevenday recording volumetric spore traps were identified under the microscope (magnification $400 \times$ ) by checking 12 vertical sweeps on each slide [17].

\section{Data analysis}

A statistical analysis was performed using Excel software package. The diversity and concentrations of the pollen identified in the honey samples were described using the average numerical values. The air pollen season was determined using the 95\% method [18], and the seasonal pollen count is expressed in the paper by a seasonal pollen index (SPI). The airborne pollen season start and end were counted as the number of days from the 1st of January (DOY). This way of expressing the pollen season allowed to indicate the pollen spectra during the particular months.

\section{Results}

\section{Honey test results}

The microscopic analysis of the honey samples identified pollen of 23 plant taxons belonging to 12 families. Rape pollen was the dominant pollen type (Fig. 1). The other part consisted of pollen of 8 genera of herbaceous plants and 15 genera of woody plants (Fig. 2).

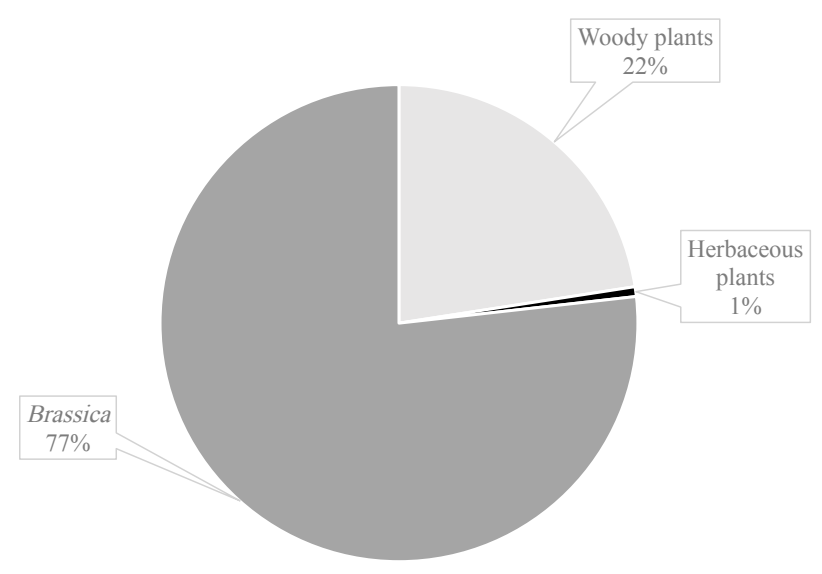

Fig. 1 The proportion of pollen in honey samples according to the dominant group.

Apple tree pollen was most common in the group of woody plants ( $86 \%$ of cases), while pear and birch pollen was found in almost every second sample. The diversity of the woody plant pollen was examined and found to be highest in the June honey. Half of the pollen identified in the June samples was from anemophilous plants. The comparison of pollen counts among woody plants demonstrated the predominance of Salix pollen (Fig. 2). This reflects the predominance of Salix flowering in the surrounding vegetation during the early spring season. The highest counts (79\% of woody plant pollen) were recorded in the May samples. Fruit tree pollen was identified in all samples, with the highest levels recorded in July. The most surprising is that pollen of woody plants flowering in early spring was identified in a small amount in the honey samples. One of the reasons why Alnus and Betula pollen was found in September could be related to seed distribution.

As noted above, rape pollen prevailed in all the samples in the group of herbaceous plants (Fig. 1). The rape pollen count in the samples made up more than $45 \%$ of all the pollen identified since June. Calluna Salisb. and Sinapis L. pollen counts in the honey samples were highest among pollen of herbaceous plants. Calluna accounted for $44 \%$ of pollen of herbaceous plants in June and Sinapis accounted for 65\% in the July honey samples. The July samples (Fig. 3) showed the highest floral diversity of herbaceous plants (6 genera).

\section{Airborne pollen results}

Pollen identified in air samples collected in Šiauliai belonged to 12 woody plants and 7 herbaceous plant families/ genera. In 2013, the pollen season in Lithuania started later than usual [19] and extended from April until September (Fig. 4).

In general, two thirds of the total anemophilous woody plants pollen recorded in this study was registered in April. The pollen season began with the detection of Betulaceae 

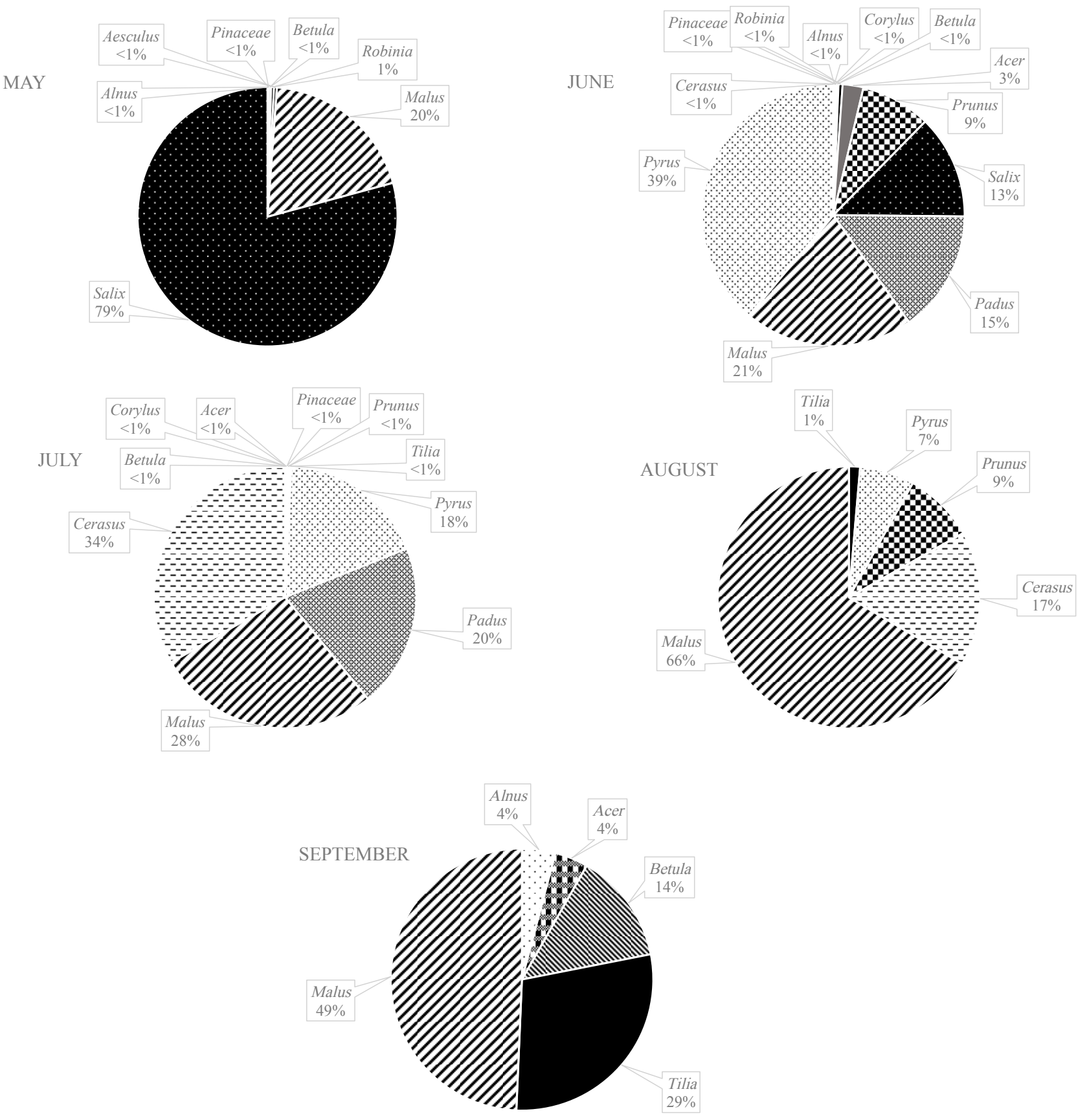

Fig. 2 Dynamics of woody plant pollen found in honey from May to September 2013.

family pollen in the air: Alnus and Corylus were recorded 4 days earlier than Betula. The diversity of airborne pollen from woody plants became lower in the second half of May. Airborne Pinaceae (SPI = 8848) and Alnus (SPI = 2599) pollen counts were high in this group. Compared to other cases, these plants spread pollen in a relatively short 10-day period.

In 2013, pollen from herbaceous plants was first recorded in May. In Lithuania, the pollen seasons of herbaceous plants are usually long; they last longer than a month. Poaceae pollen can be detected throughout the summer. However, among herbaceous plants the peak levels are recorded for the genus Urtica (SPI =6779). Interestingly, the pollen from entomophilous Brassicaceae plants can also be found in the air samples, although their counts are low $(\mathrm{SPI}=58)$.

\section{Comparison of pollen identified in honey and air samples}

The botanical diversity of pollen from the honey and air samples in different months indicates 10 morphotypes: 8 of woody plants and 2 of herbaceous plants, in both the honey and air samples (Tab. 1).

The number of coinciding cases was least in August. In July, 7 cases of pollen from the same plant genus or family were identified in both the air and honey samples. Despite the fact that the number of coincidental cases was less in May than in July, the relative coincidence rate (32\% and 29\%, respectively) remained higher due to the lower diversity of pollen in the samples. The assessment of the coinciding cases showed the highest frequency of Betulaceae pollen (in four-fifths of both types of the samples). 

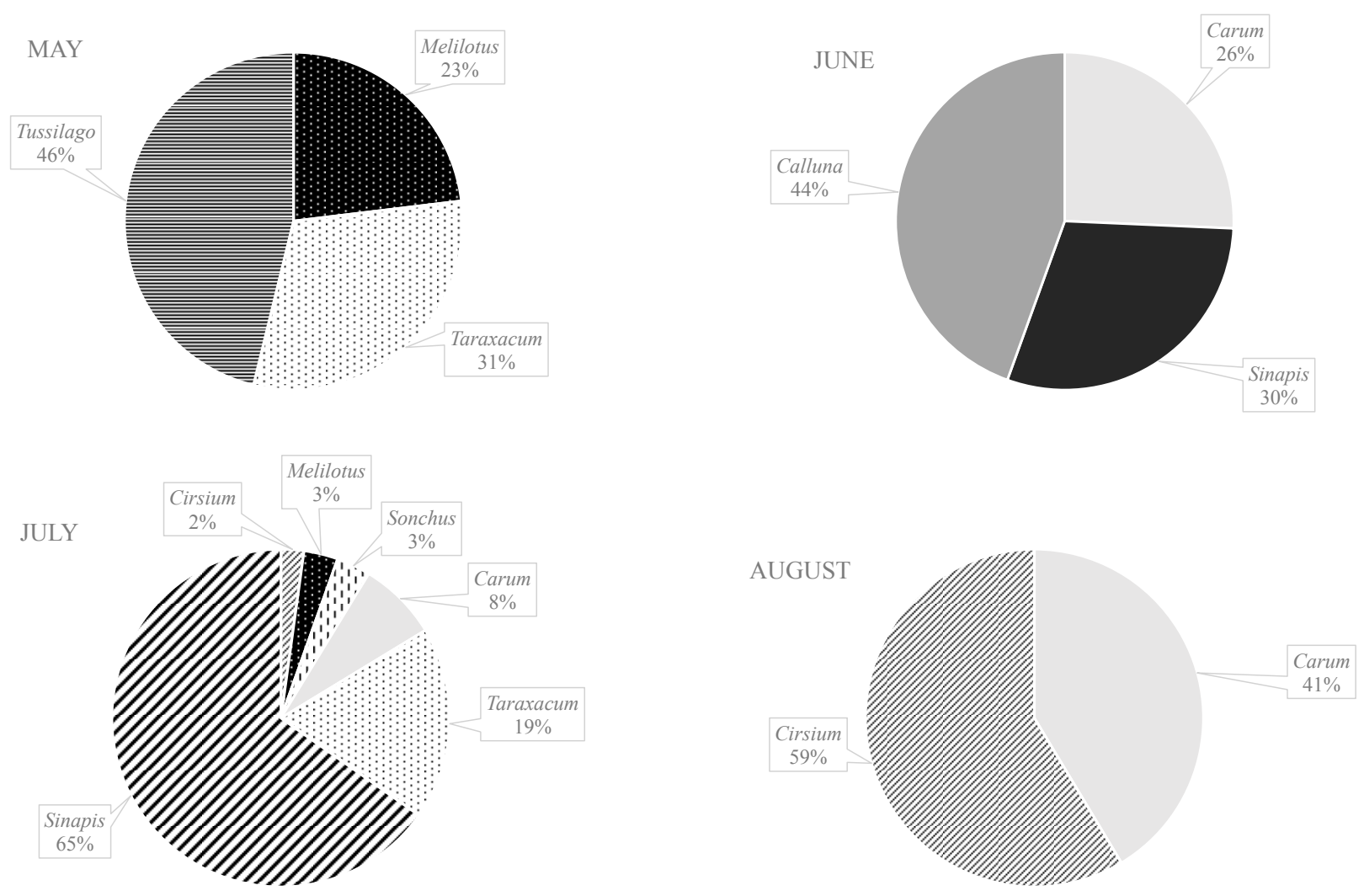

Fig. 3 Participation of pollen from herbaceous plant found in honey collected from May to September in 2013.

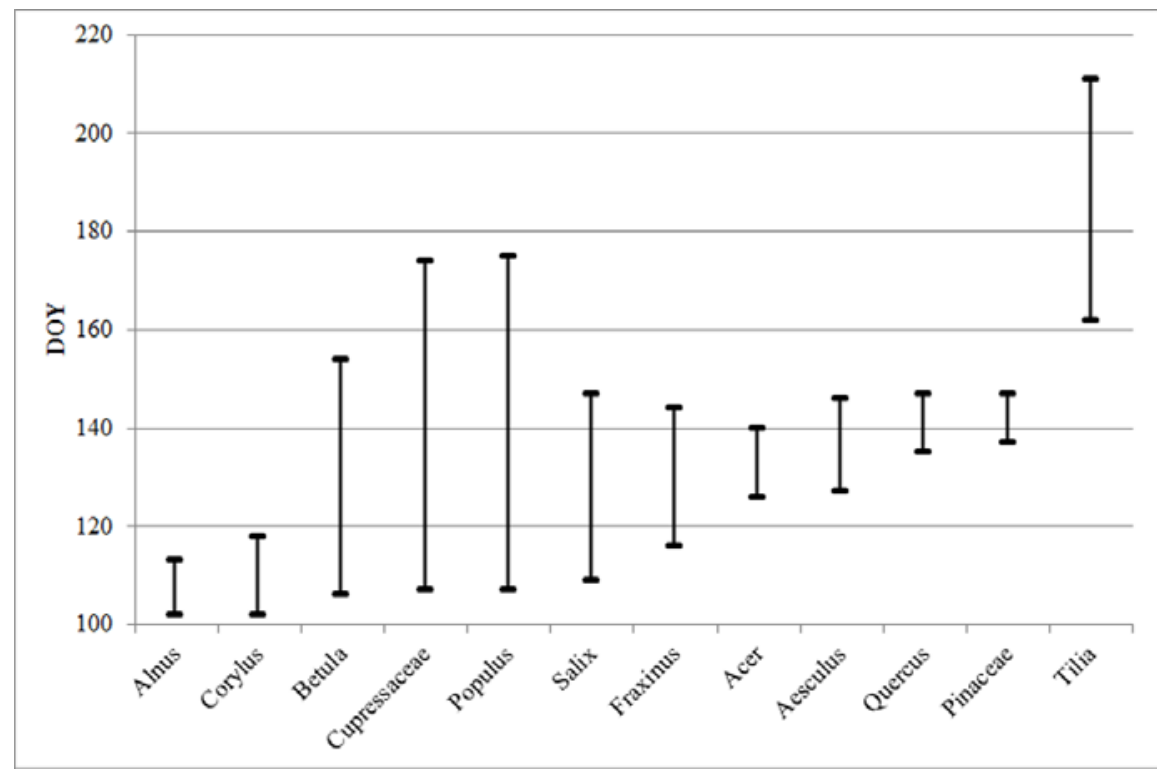

Fig. 4 The duration of the particular airborne pollen seasons.

The comparison of pollen abundance in the honey and in the air according to a specific morphotype is shown on Fig. 5. In the honey samples, the Salix pollen participation has been the highest among airborne pollen during the testing period. The Salix pollen count recorded in the air accounted for merely $2 \%$ among 9 morphotypes. On the other hand, Pinaceae pollen prevailed in the air samples, but its counts were lower in the honey (0.43\%). Acer and Tilia are recognized as typically entomophilous. Despite this, our study revealed a similar ratio of pollen of these 
Tab. 1 Pollen types in the air (A) and honey (H) samples.

\begin{tabular}{|c|c|c|c|c|c|c|c|}
\hline Pollen type & March & April & May & June & July & August & September \\
\hline \multicolumn{8}{|c|}{ Woody plants } \\
\hline Acer* & & & $\mathrm{A}$ & A H & $\mathrm{H}$ & & $\mathrm{H}$ \\
\hline$A \ln u s^{*}$ & A & A & A H & A H & A & A & $\mathrm{H}$ \\
\hline Betula* & A & A & A H & A H & A H & A & A H \\
\hline Aesculus & & & A H & A & & & \\
\hline Cerasus & & & & $\mathrm{H}$ & $\mathrm{H}$ & $\mathrm{H}$ & \\
\hline Corylus* & A & A & A & A H & $\mathrm{H}$ & A & \\
\hline Cupresaceae* & & A & A & A & A & A & \\
\hline Fraxinus* & & A & & & A & & \\
\hline Malus & & & $\mathrm{H}$ & $\mathrm{H}$ & $\mathrm{H}$ & $\mathrm{H}$ & $\mathrm{H}$ \\
\hline Padus & & & & $\mathrm{H}$ & $\mathrm{H}$ & & \\
\hline Pinaceae & A & A & A H & A H & A H & A & A \\
\hline Pyrus & & & & $\mathrm{H}$ & $\mathrm{H}$ & $\mathrm{H}$ & \\
\hline Populus & & A & A & $\mathrm{A}$ & A & & $\mathrm{A}$ \\
\hline Prunus & & & & $\mathrm{H}$ & $\mathrm{H}$ & $\mathrm{H}$ & \\
\hline Quercus* & & & A & & & & \\
\hline Robinia & & $\mathrm{H}$ & & $\mathrm{H}$ & & & \\
\hline Salix & & A & A H & A & A & & \\
\hline Tilia & & & A & A & A H & A H & A H \\
\hline \multicolumn{8}{|c|}{ Herbaceous plants } \\
\hline Ambrosia* & & & & & A & A & A \\
\hline Apiaceae* & & & A & $\mathrm{AH}$ & $\mathrm{AH}$ & $\mathrm{H}$ & \\
\hline Artemisia* & & & & A & A & A & A \\
\hline Brassicaceae & & & A H & A H & A H & $\mathrm{H}$ & $\mathrm{H}$ \\
\hline Calluna & & & & $\mathrm{H}$ & $\mathrm{H}$ & & \\
\hline Chenopodium ${ }^{*}$ & & & & $\mathrm{~A}$ & A & A & A \\
\hline Cirsium & & & & & $\mathrm{H}$ & $\mathrm{H}$ & $\mathrm{H}$ \\
\hline Melilotus & & & $\mathrm{H}$ & & $\mathrm{H}$ & & $\mathrm{H}$ \\
\hline Poaceae* & & & A & A & A & A & A \\
\hline Sinapis* & & & & $\mathrm{H}$ & $\mathrm{H}$ & & \\
\hline Sonchus & & & & & $\mathrm{H}$ & & \\
\hline Taraxacum & & & $\mathrm{H}$ & & $\mathrm{H}$ & & $\mathrm{H}$ \\
\hline Tussilago & & & $\mathrm{H}$ & & $\mathrm{H}$ & & \\
\hline Urtica & & & $\mathrm{A}$ & $\mathrm{A}$ & A & A & $\mathrm{A}$ \\
\hline
\end{tabular}

* Allergenic pollen types.

morphotypes both in the air and honey. Possibly in the air we found pollen of Acer negundo. This anemophilous plant species is very common in urban territories and has high pollen production. Accordingly, the genus Acer could be represented by different species in honey.

\section{Discussion}

Pollen is an essential honey component determining the nutrition value and its valuable biological properties [10]. Honey pollen diversity depends on the plant species 


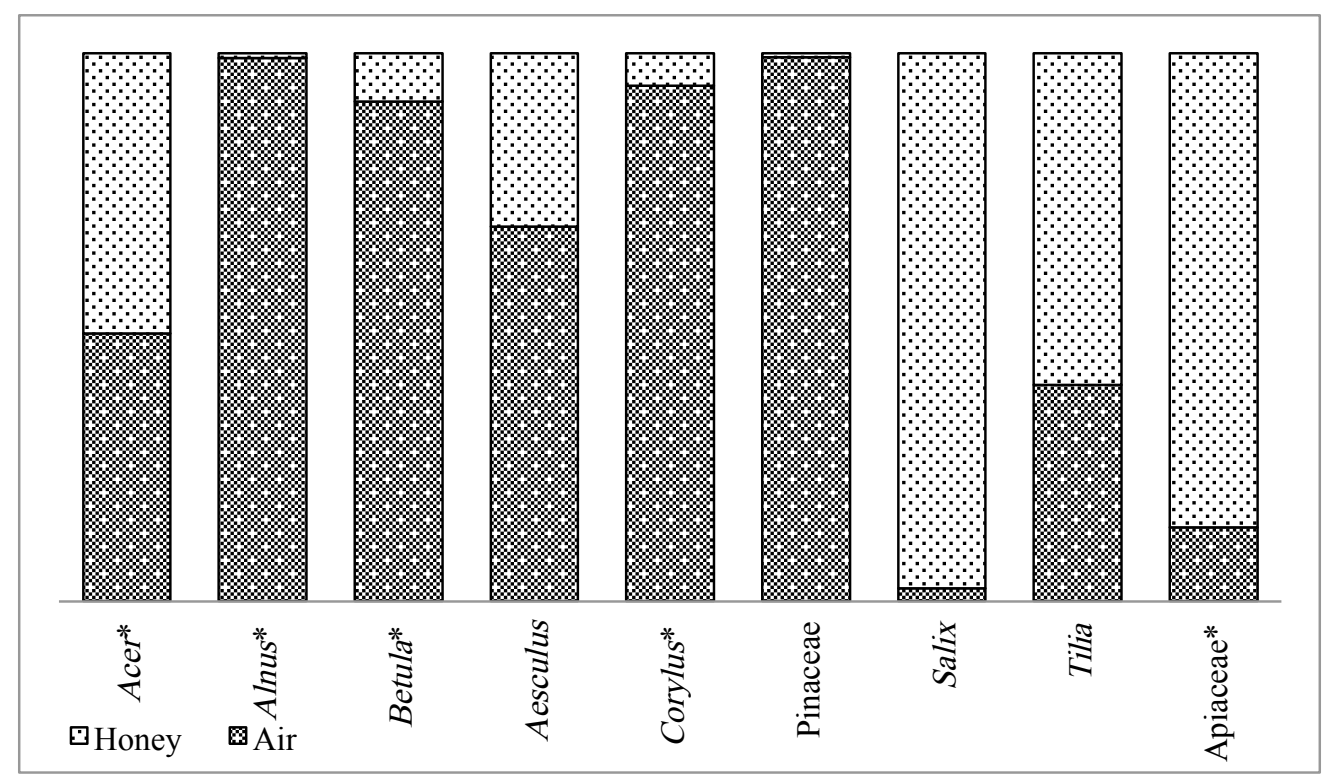

Fig. 5 Comparison of relative pollen abundance in the air and honey. * Allergenic pollen.

diversity in the surrounding of the apiary and the condition of the honey bee colony [20]. Climatic and meteorological factors, plant biological features and ecological conditions are essential to pollen abundance and emission intensity, therefore the concentrations of pollen in honey vary from year to year [21]. Lithuania does not have completely pure honey [22] containing pollen from the same species of plants because various plant species blossom at the same time. Louveaux with co-authors [16] classified honey containing more than $45 \%$ of one type of pollen to monofloral honey. Our research showed that rape pollen prevailing in honey collected in 2013 accounted for $77 \%$ of the total pollen count estimated in honey. Therefore, it can be assumed that in spite of the fact that other 24 pollen morphotypes were identified in the other samples (23\%), the actual floral composition of honey, which can be very important to the consumer, can be missing. We assume that it is important to communicate allergenic pollen concentrations in bee products.

Allergenic pollen usually refers to anemophilous plants. However, the amount of anemophilous pollen in honey is relatively low. Our study revealed Corylus, Alnus, Betula, and Salix pollen in the honey samples. The pollen counts identified as the members of Betulaceae family were low and Salix pollen prevailed in the May honey samples. This is a fairly typical result for Lithuania [23]. Estonian scientists also point out that Corylus, Alnus and Salix are the most common honey plants in Estonia from early spring to June. Pollen from these genera can cause allergic reactions in sensitive people. Pollen proteins contained in the honey are known to cause allergic reactions [24]. Furthermore, allergy to honey may be due to airborne Asteraceae pollen or cross-reacting bee venom components [25]. Allergy caused by pollen present in honey is very rare but can cause anaphylactic reaction [26]. A case report of anaphylaxis provoked by the consumption of honey has been described recently [27]. However, studies on the effects of allergenic pollen in bee products on human health are scarce.
The examination of pollen allergenic aspects is more likely to be linked with the respiratory system activity than the peculiarities of food consumption. The human immune system responds to pollen allergens inhaled together with air and causes allergic reactions or even make the progress of some diseases. There is no accurate identification of sensitization thresholds for allergens or particles, and allergy cases are analyzed in the light of pollen morphotypes and particle concentrations [28]. High concentrations of alder pollen and atypically low birch pollen counts were found in the years of our study (Tab. 1). Generally, there are up to several hundred grains of birch pollen in a cubic meter of air in Lithuania with the peak daily concentration of 104 pollen grains. This is in accordance with reports from other northern European countries [14]. The relatively low anemophilous plant pollen concentration in the air cannot be seen as a critical factor that led to a relatively small pollen count of the given morphotype in the honey (Fig. 5). Similarly, alder and pine tree pollen counts on individual days amounted to 800 and 3139 pollen $/ \mathrm{m}^{3}$, respectively, but showed low levels in the honey. The examination of the anemophilous pollen load led to the conclusion that the pollen could potentially get into the hive not only with bee-collected pollen but also with the airflow.

Moreover, the knowledge about allergenic pollen in honey is useful for allergic patients, allergy doctors, pharmaceutical companies. Honey consumption is recommended in seasons other than the pollen season as a preventive measure potentially reducing allergic effects on health. The role of honey in the treatment of allergic rhinitis has been controversial so far. The study conducted at the University of Connecticut does not confirm the widely held belief that honey relieves the symptoms of allergic rhinoconjunctivitis [29]. Some subsequent researches into the use of honey in the treatment suggest that the consumption of honey that contains allergenic pollen could be an integral part of pollen allergy therapy [30]. The idea of honey consumption was supported 
by Malaysian scientists who claimed that the ingestion of a high dose of honey had a significant complementary effect in improving the overall symptoms in AR patients compared to the placebo [13]. Our tests indicate that the alarming increase in the number of allergic people should lead to new attitudes towards the custom of honey consumption in respect of allergenic pollen diversity and quantity. Following the study, it should be noted that anemophilous allergenic

\section{Acknowledgments}

We acknowledge the anonymous reviewers for their useful comments. The research was supported by Siauliai University.

\section{Authors' contributions}

The following declarations about authors' contributions to the research have been made: design of the study: IŠ, L $\breve{S}, A N M$, VP; conducting of the

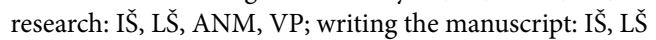

\section{Competing interests}

No competing interests have been declared.

\section{References}

1. FAOSTAT [Internet]. Food and agricultural commodities production. 2015 [cited 2015 Oct 27]; Available from: http://faostat.fao.org/ site/291/default.aspx

2. Čeksterytė V. Augalų žiedadulkių, randamų Lietuvos meduje. Kèdainiai: Spausdvita; 2012.

3. Bastl K, Kmenta M, Geller-Bernstein C, Berger U, Jäger S. Can we improve pollen season definitions by using the symptom load index in addition to pollen counts? Environ Pollut. 2015;204:109-116. http:// dx.doi.org/10.1016/j.envpol.2015.04.016

4. Ugolotti M, Pasquarella C, Vitali P, Smith M, Albertini R. Characteristics and trends of selected pollen seasons recorded in Parma (northern Italy) from 1994 to 2011. Aerobiologia. 2015;31(3):341-352. http:// dx.doi.org/10.1007/s10453-015-9368-4

5. Abou-Shaara HF. The foraging behaviour of honey bees, Apis mellifera: a review. Vet Med (Praha). 2014;59(1):1-10.

6. Hammond G, Blankenship M, Roles E. Animal Diversity Web [Internet]. Apis mellifera. 2009 [cited 2015 Sep 4]; Available from: http:// animaldiversity.org/accounts/Apis_mellifera/

7. Beekman M, Ratnieks FLW. Long-range foraging by the honey-bee, Apis mellifera L. Funct Ecol. 2000;14(4):490-496. http://dx.doi. org/10.1046/j.1365-2435.2000.00443.x

8. Piana ML, Belligoli P, Persano Oddo L, Piperno S. Pollen analysis of royal jelly: contribution to analytical methods and characterization. Apiacta. 2006;41:28-43.

9. Bogdanov S, Jurendic T, Sieber R, Gallmann P. Honey for nutrition and health: a review. J Am Coll Nutr. 2008;27(6):677-689. http:// dx.doi.org/10.1080/07315724.2008.10719745

10. Alvarez-Suarez JM, Tulipani S, Romandini S, Bertoli E, Battino M. Contribution of honey in nutrition and human health: a review. Med J Nutrition Metab. 2010;3(1):15-23. http://dx.doi.org/10.1007/ s12349-009-0051-6

11. Ščevková J, Dušička J, Mičieta K, Somorčík J. Diurnal variation in airborne pollen concentration of six allergenic tree taxa and its relationship with meteorological parameters. Aerobiologia. 2015;31(4):457-468. http://dx.doi.org/10.1007/s10453-015-9379-1

12. Calderon MA, Demoly P, van Wijk RG, Bousquet J, Sheikh A, Frew A. et al. EAACI: a European declaration on immunotherapy. Designing the future of allergen specific immunotherapy. Clin Transl Allergy. 2012;2(1):1-8. http://dx.doi.org/10.1186/2045-7022-2-20

13. Asha’ari ZA, Ahmad MZ, Din W, Jihan WS, Hussin C, Maraina C. Ingestion of honey improves the symptoms of allergic rhinitis: pollen constituted $44 \%$ of the total floral composition of the honey pollen. Given that allergen release per pollen varied substantially and pollen released different amounts of allergen depending on humidity [31], it would be appropriate to identify the allergenic pollen load during assessing honey quality and to communicate the allergenic pollen content to the consumers.

evidence from a randomized placebo-controlled trial in the east coast of Peninsular Malaysia. Ann Saudi Med. 2013;33(5):469-475.

14. Šaulienė I, Šukienė L, Severova E, Kalnina L. Comparison of Alnus, Corylus, Betula pollen seasons in Riga, Moscow and Vilnius. Aerobiologia. 2014;30(4):423-433. http://dx.doi.org/10.1007/s10453-014-9341-7

15. Katelaris CH, Burke TV, Byth K. Spatial variability in the pollen count in Sydney, Australia: can one sampling site accurately reflect the pollen count for a region? Ann Allergy Asthma Immunol. 2004;93(2):131-136. http://dx.doi.org/10.1016/S1081-1206(10)61464-0

16. Louveaux J, Maurizio A, Vorwohl G. Methods of melissopalynology. Bee World. 1978;59(4):139-157. http://dx.doi.org/10.1080/00057 72X.1978.11097714

17. Galán C, Smith M, Thibaudon M, Frenguelli, G, Oteros J, Gehrig R. et al. Pollen monitoring: minimum requirements and reproducibility of analysis. Aerobiologia. 2014;30(4):385-395. http://dx.doi.org/10.1007/ s10453-014-9335-5

18. Emberlin J, Mullins J, Corden J, Millington W, Brooke M, Savage $\mathrm{M}$, et al. The trend to earlier birch pollen seasons in the UK: a biotic response to changes in weather conditions?. Grana. 1997;36(1):29-33. http://dx.doi.org/10.1080/00173139709362586

19. Šaulienė I, Šukienè L, Kainov D, Greičiuvienė J. The impact of pollen load on quality of life: a questionnaire-based study in Lithuania. Aerobiologia. 2015 (in press). http://dx.doi.org/10.1007/s10453-015-9387-1

20. Ketola J, Hakala K. Impact of use of neonicotinoid insecticides on honey bees in the cultivation on spring oilseed crops in Finland [Internet]. 2014 [cited 2015 Sep 4]; Available from: http://www.mtt. fi/mttraportti/pdf/mttraportti157.pdf

21. Puusepp L, Koff T. Pollen analysis of honey from the Baltic region, Estonia. Grana. 2014;53(1):54-61. http://dx.doi.org/10.1080/00173 134.2013.850532

22. Karosas P. Bitininkavimo mokykla. Kaunas: Ūkininko patarejas; 2005.

23. Čeksterytė V, Kurtinaitienè B, Balžekas J. Pollen diversity in honey collected from Lithuania's protected landscape areas. Proceedings of the Estonian Academy of Sciences. 2013;62(4):277-282. http://dx.doi. org/10.3176/proc.2013.4.08

24. Bauer L, Kohlich A, Hirschwehr R, Siemanna U, Ebner H, Scheiner O. et al. Food allergy to honey: pollen or bee products? Characterization of allergenic proteins in honey by means of immunoblotting. J Allergy Clin Immunol. 1996;97(1):65-73. http://dx.doi.org/10.1016/ S0091-6749(96)70284-1

25. Helbling A, Peter CH, Berchtold E, Bogdanov S, Müller U. Allergy to honey: relation to pollen and honey bee allergy. Allergy. 1992;47(1):4149. http://dx.doi.org/10.1111/j.1398-9995.1992.tb02248.x

26. Weissenstein A, Luchter E, Bittmann S. Medical honey and its role in paediatric patients. Br J Nurs. 2014;23(6):S30-S34. http://dx.doi. org/10.12968/bjon.2014.23.Sup6.S30

27. Tuncel T, Uysal P, Hocaoglu AB, Erge DO, Firinci F, Karaman O, et al. Anaphylaxis caused by honey ingestion in an infant. Allergol Immunopathol (Madr). 2011;39(2):112-113. http://dx.doi.org/10.1016/j. aller.2010.04.007

28. de Weger L A, Bergmann KC, Rantio-Lehtimäki A, Dahl Å, Buters J, Déchamp C et al. Impact of pollen. In: Sofiev M, Bergmann KC, editors. Allergenic pollen. Dordrecht: Springer; 2013. p. 161-215. http://dx.doi.org/10.1007/978-94-007-4881-1_6

29. Rajan TV, Tennen H, Lindquist RL, Cohen L, Clive J. Effect of 
ingestion of honey on symptoms of rhinoconjunctivitis. Ann Allergy Asthma Immunol. 2002;88(2):198-203. http://dx.doi.org/10.1016/ S1081-1206(10)61996-5

30. Saarinen K, Jantunen J, Haahtela T. Birch pollen honey for birch pollen allergy - a randomized controlled pilot study. Int Arch Allergy Immunol. 2011;155(2):160-166. http://dx.doi.org/10.1159/000319821

31. Buters J, Prank M, Sofiev M, Pusch G, Albertini R, Annesi-Maesano I, et al. Variation of the group 5 grass pollen allergen content of airborne pollen in relation to geographic location and time in season. J Allergy Clin Immunol. 2015;136(1):87-95. http://dx.doi.org/10.1016/j. jaci.2015.01.049

\section{Porównanie zawartości pyłku w powietrza i miodach}

\section{Streszczenie}

Miód jest produktem spożywczym stosowanym w żywieniu ludzi od czasów starożytności, a obecnie cieszy się dużą popularnością. Posiada walory terapeutyczne, profilaktyczne i wzmacniające. Jednym z istotnych składników miodu jest pyłek, który decyduje o jakości i rodzaju miodu. Pyłek występujący w powietrzu stanowi coraz większe zagrożenie dla osób wrażliwych. Dlatego określenie ewentualnego występowania pyłku alergennego w miodzie jest istotne. Celem pracy było określenie korelacji pomiędzy zawartością pyłku w aeroplanktonie a jego zawartością w próbkach miodów. Badania prowadzono na Litwie. Zastosowano standardowe metody określania zawartości pyłku w powietrzu i miodach. Stwierdzono 10 morfotypów: 8 roślin drzewiastych oraz 2 roślin zielnych, zarówno w próbkach miodu jak i w powietrzu. Suma ziaren pyłku Salix w miodzie była najwyższa spośród pyłku występujaccego w powietrzu w okresie od maja do września. Pyłek o właściwościach alergicznych, pochodzący od roślin wiatropylnych, stanowił $44 \%$ całej ilości pyłku stwierdzanego w miodach. 